Article

\title{
CURRENT POLICY ON DOMESTIC VIOLENCE: A MOVE IN THE RIGHT DIRECTION OR A STEP TOO FAR?
}

\author{
Kirsty Welsh \\ University of Sheffield, Sheffield, UK \\ Correspondence: Kirsty Welsh, School of Law, University of Sheffield, Bartolome House, Winter \\ Street, Sheffield S3 7ND, UK. \\ E-mail: kirsty.welsh@shef.ac.uk
}

\begin{abstract}
This paper reflects on doctoral research conducted in Northern England to explore understandings about and approaches to domestic violence. Specifically, it considers the problem's increasing popularization as an "...horrific crime..." and wonders whether and how its increasing celebration as a "collective cause" could marginalize the feminist analyses and action that has, for over 30 years, been so central to endeavours to challenge male violence in the home. Focusing on two issues, gender and crime prevention, the paper examines local and national policy and practice on domestic violence in order to explore whether current policy is a move in the right direction or whether it has taken a step too far.
\end{abstract}

\section{Keywords}

domestic violence; policy; responses; gender; crime prevention

Crime Prevention and Community Safety (2008) 10, 226-248.

doi:10.1057/cpcs.2008.7

\section{Introduction}

I ncreasingly in England and Wales, the message that domestic violence is an enormous and pressing social problem abounds. A high-profile storyline in the BBC programme, EastEnders, the Spring 2003 $\mathrm{BBC}$ domestic violence season, Hitting Home, and storylines in ITV's 
Coronation Street are just some of the channels through which this message has been spread. Other recent campaigns include those run by the domestic violence charity, Refuge, Don't Ignore It, which featured in national cinema screens during 2003, and the February 2007 "Act Until Women And Children Are Safe" campaign, run by the national domestic violence charity Women's Aid and featuring several "celebrity" women. Women's Aid has also collaborated with the high-street retailers, The Body Shop, TopShop and House of Fraser. The message that domestic violence is a serious issue that should concern us all is also increasingly voiced in government circles and domestic violence now finds itself at the heart of government thinking on health (see DoH, 1995a, b, 1997, 1999, 2000; DoH et al., 1998); housing (DETR et al., 1999) and, especially, crime and crime prevention (Women's Unit, 1999; Home Office, 2000, 2002, 2003, 2005; Home Office et al., 2000).

Now, domestic violence appears to be something of a cause célèbre in popular and government discourse. But this has not always been the case. Until recently, domestic violence has largely been the concern of the women's movement and traditional understandings of, and approaches to, the issue have been strongly associated with feminism and women's liberation. Indeed, in the late 1960s and early 1970s, the women's liberation movement provided the "...base of membership and overall perspective..." (Dobash and Dobash, 1992, p 16) from which numerous issues were conceptualized, considered and challenged. Men's violence to their women partners was one such issue. From women's liberation came the development of the refuge movement and the establishment of services to assist battered women and their children.

Feminist analyses in the refuge movement and the subsequent National Women's Aid Federation, now Women's Aid Federation England (WAFE), have viewed domestic violence, and all male violence against women, as about male domination and power and thus as a gendered phenomenon. Indeed, most feminist theorizing about domestic violence centres on making connections between the power that men exercise in their personal relationships and the power that men exercise as a group. Alongside, for over 30 years in the refuge movement, women have worked with women for women to establish services to challenge male violence. These services have been grounded in three guiding principles - self-help, self-determination and empowerment (Sutton, 1978; Dobash and Dobash, 1980; Hague and Malos, 1998).

In this paper, I reflect on doctoral research conducted in a county in Northern England, fictitiously named Hillshire, and focused on two areas in that county, fictitiously named Pittplace and Steelsite, to examine these transitions in domestic violence and its prominence, populism and politics. I examine developments in local and national policy and practice on domestic violence in order to explore whether and how increasingly loud popular and policy encouragements to "take on" the problem are silencing feminist voices in understandings of and approaches to domestic violence. The paper provides, 
then, observations about current policy developments on domestic violence but also aims to problematize whether and how, in the drive to promote domestic violence as a serious crime and a collective cause, these developments could be distancing the feminist analyses and action that have been so important to women's endeavours to challenge and survive male violence in the home.

In this examination, I focus on two issues - gender and crime prevention since developments around both appear connected to the transitions in domestic violence from an issue grounded in feminist praxis around gender, violence, sexual politics to an issue that appears increasingly mainstream and populist. Indeed, both issues, gender and crime prevention, centre on how "the problem" and the "proper response" to it come to be conceptualized. The first concerns whether domestic violence is seen as a gendered issue, where women are overwhelmingly victims of men's violence and have their needs therefore prioritized, or a gender-neutral issue, affecting both men and women as victims and offenders and attracting concern for both. The second concerns whether domestic violence is seen as a crime prevention issue or a victimization/violence against women issue and, more generally, the role that traditional crime prevention measures assume in responses to the problem.

In the discussions that follow, I first detail the research that grounds the reflections in the paper before moving to examine in greater, though necessarily wordlimited, detail the political and philosophical background to the moves that appear to be occurring on domestic violence - the "discovery" of the problem and the development of action and analyses around this and other gendered violence. I then turn to the research findings and consider differences within and between the two research areas in relation to the two issues, gender and crime prevention, comparing the differences and difficulties at local level with those seen in national policy discourse and developments. I suggest that, in some areas and analyses, there have been moves from the feminist (gendered) analysis pioneered in the refuge movement and Women's Aid to a much more genderneutral position and, in addition, that domestic violence is increasingly being approached as a Home Office crime prevention issue rather than a women's liberation or victim services issue. Having set out these moves on gender and crime prevention, I go on to consider the tensions that follow from them in order to consider the paper's central problematic - does the increasing focus on and concern about domestic violence represent a step in the right direction in that it is a lasting move to bring the problem out from behind closed doors or do the philosophical, political and practical contradictions that appear in this encouragement suggest that current policy has, rather, taken a step too far?

\section{The research}

Alongside the more general encouragement in policy pronouncements to take on domestic violence has been a particular encouragement to do so in 
partnership. Since the mid-1990s, there has been an increasing focus in government discourse on the partnership or multi-agency approach as the favoured response to domestic violence. At the same time, there has been a push to partnership initiatives - multi-agency groupings, sometimes called forums or fora, between agencies and organizations in the local area - as the vehicle through which this approach should be delivered. This focus on partnership to challenge violence and abuse that happens between partners (Welsh, 2008) formed the background to the research conducted in Pittplace and Steelsite (see Welsh, 2003).

At the time of time of the research, Pittplace was a town with a population of around 250,000, under $1 \%$ of which were from ethnic minority backgrounds. Following the closure of local collieries in the 1980s, thousands of mining jobs were lost and employment in the area remained below the national average. In the 1970s, crime levels were considerably below the national average but, by the late 1990 s, crime rates were above those nationally. Concerns about this increase led to the development in 1996 of Pittplace's first partnership grouping focused on crime prevention. As regards domestic violence provision, as in most areas, dedicated support services in Pittplace were found largely in the voluntary sector. At the time of the research, there were two organizations offering specialist services around domestic violence - a non-residential support group and a refuge (neither were affiliated to Women's Aid). Pittplace also had Rape Crisis and Victim Support organizations. Within the state sector, dedicated services were provided by police domestic violence officers but, within other agencies, it was left to "champions" to maintain a focus on domestic violence within their services (Welsh, 2008).

Steelsite was a city with a population of over 500,000 , about $7 \%$ of which were from minority ethnic backgrounds. Again, a collapse in traditional heavy industry in the local area has caused considerable unemployment and, notwithstanding a drive to diversification, unemployment in Steelsite remained above the national average at the time of the research. The city has a long history of work around community safety, which developed first around the city council. Both the city council and the police in the area have worked closely with the university in Steelsite around crime and crime prevention. As regards domestic violence, at the time of the research, there were several organizations working in the voluntary sector to support women and their children. Three dedicated community groups were supported in their work by a Women's Aid refuge, a WAFE-affiliated refuge and an Asian's women's refuge. Steelsite also had Rape Crisis and Victim Support organizations but, again, within the state sector, dedicated services were provided only by police domestic violence officers.

Between December 1998 and June 2001, three multi-agency domestic violence initiatives in these research areas were examined - the Pittplace Domestic Violence Topic Group (PDVTG), the Pittplace Multi-Agency Domestic 
Violence Forum (PMADVF) and the Steelsite Domestic Violence Forum (SDVF). ${ }^{1}$ Alongside, numerous interviews were conducted in the agencies and organizations in Pittplace and Steelsite that provided services on and around domestic violence in these areas, whether to women, children or abusers, including those that attended the three initiatives observed. ${ }^{2}$

Although setting out to examine the partnership response to domestic violence in Pittplace and Steelsite, the research also revealed much about more general policy responses to the problem in these areas. It certainly revealed much about how changes and developments in national policy are encountered and experienced locally in areas such as Pittplace and Steelsite. Throughout the paper, I explore these local policy responses and, in doing so, hope to advance discussions about both local and national policy developments on domestic violence, through a focus on the approaches to both gender and crime prevention in Pittplace and Steelsite.

\section{Domestic violence}

Although by no means a recent phenomenon, ${ }^{3}$ domestic violence has traditionally been hidden from popular and governmental discourse. Towards the end of the 19th century, it first started to be recognized as a social problem but the public concern around this time was short-lived. Indeed, domestic violence did not trouble our collective conscience until the second half of the next century when, in the late 1960s and early 1970s, the women's liberation movement emerged. From the women's liberation movement came the refuge movement, which began in Britain in 1972 when feminists established a women's centre in Chiswick, London - "the Goldhawk Road Women's Liberation Movement Centre". When a woman escaping her abusive husband was allowed to use the centre as emergency, temporary accommodation, the centre became a $24 \mathrm{~h}$ refuge for battered women. By April 1973, it had an average daily population of 25 women and children but there was much overcrowding - "the refuge was literally bursting at the seams" (Dobash and Dobash, 1992, p 63). The overcrowding made a strong point about demand and generated considerable popular interest.

Indeed, it is this double role that has made the refuge so important to action against domestic violence. For over three decades, refuges have provided women with accommodation. In doing so, they have also challenged the social order in which women are dependent on others for their basic accommodation needs. By their very existence, refuges have demonstrated women's oppression in the family and society and have demanded that domestic violence be seen in a social, economic, cultural and political context of male domination and female disadvantage. As the Dobashes put it, "the refuge stands simultaneously as an essential aspect of supporting women subject to male violence and of rejecting patriarchal control of women" (Dobash and Dobash, 1992, p 63). 
The Rape Crisis Centres that developed in the 1980s were to have the same duality of purpose - “...RCCs were never just about service provision but about making the fundamental connection between practice and theory and translating that into campaigning for social change..." (Foley, 1996, p 167).

Most ${ }^{4}$ feminist theorizing about domestic violence has also revolved around elucidating the connections between men's collective and individual power. As Bograd put it in the pioneering Feminist Perspectives on Wife Abuse:

Our society is structured along the dimension of gender: Men as a class wield power over women...The reality of domination at the social level is the most crucial factor contributing to and maintaining wife abuse at the personal level. (1988, p 14)

Male violence is explained as resting in, reflecting and, ultimately, reinforcing structured power relations between men and women. In other words, the causes of domestic violence are found in a patriarchal social structure which embodies male oppression of women (Mooney, 2000) but a consequence of male violence in the home (and, indeed, the condoning of, and effective colluding in, such violence by society, the state and its services) is to support and sustain this social order of male supremacy and female subordination.

Clearly, then, within the feminist framework that has traditionally dominated how domestic violence has been understood and approached, women are conceptualized as victims/survivors while men are conceptualized either as offenders or as “...complicit bystanders..." (Gadd et al., 2002, p 3), who have failed to challenge other men's abuse and violence and have thus colluded in, sustained and gained further advantage from women's victimization. Ann Grady suggests that this feminist framework has been so dominant in the analysis of domestic violence that "...it has led to the creation of a domestic violence stereotype: that domestic violence is male-on-female abuse..." (2002, p 77). ${ }^{5}$ Alongside, the refuge movement has provided services to women and women alone. As the WAFE Director, Nicola Harwin, explains, the Women's Aid response has been grounded in “...recognising the gender and power dynamics of women abuse, and creating autonomous, women-only services...” (1999, p 25).

In the following discussions, I turn to examine how the work on men and power that characterized the pioneering analyses and action against domestic violence had come to be seen in the two research areas, Pittplace and Steelsite, and compare the difficulties in these particular areas in this regard with moves that seem to have occurred more generally in discussion and developments on and around domestic violence. I examine these issues first in relation to gender and second in relation to crime prevention. 


\section{It is important to include men}

\section{Pittplace}

In Pittplace, some individuals were clearly committed to a gender-neutral approach to domestic violence. For example, a focus group interview with volunteers from the town's one specialist domestic violence support organization, the Pittplace Domestic Violence Group/Helpline, clearly illustrated some individuals' commitment to gender-neutrality. During the focus group discussion, it became obvious that these volunteers were concerned about approaches that centred on domestic violence as men's abuse of women. Volunteers wanted to "...include men..." - to emphasize that domestic violence is not gendered but that "...men are victims too...". Indeed, when questioned whether men face an "...equal risk of victimization...", the volunteers said, categorically, "...yes..." (although they subsequently concluded that women and men's domestic violence victimization was not “..50:50..." but was “...75:25...”, women:men).

The volunteers were also keen to claim that men's domestic violence victimization is both serious and significant and, further that women are “...just as physically violent...". This focus on women's violence, rather than men's victimization, is quite common in gender-neutral accounts of domestic violence. Also common are misogynist assumptions about women's supposed violence and abuse. Such assumptions were certainly present in the focus group in Pittplace and are seen, for example, in the following responses to questioning about the abuse that men experience as victims and about women's behaviour:

Volunteer 1: don't forget that women go through this pre-menstrual tension and that sort of thing... and women, yes, they do take it out on their husbands. Because they might be at home and they're looking after the children (and the stresses of bring up the child) - it's not easy... and they've got to take it out on somebody

Volunteer 2: [women are] just as physically violent. In fact, I think in some ways the injuries are worse because they haven't the strength that a man has (obviously) and they tend, if a row blows up and, a woman's place - in the kitchen, usually, you know, she'll pick up a knife or some sort of instrument to hit the man with

Volunteers proselytized the need to include men. One volunteer said, “...I raise this whenever I attend a meeting...”. Questioned about whether other organizations in Pittplace took a gendered approach to the issue, the same volunteer set out his opinion:

Yeah, it's not just Pittplace - it's the whole of Hillshire....it's sociologists. Men are sociologically believed to be the perpetrators - the bullies. Women are still 
believed to be the weaker sex. But there's been such a lot of change over the last two decades that it no longer rings true

Yet, these volunteers' own organization, the Pittplace Group/Helpline, took a gender-neutral approach to domestic violence, providing services to both women and men who had experienced or who were experiencing domestic violence.

In Pittplace's multi-agency groupings, there was no obvious overall commitment to either a gendered or a gender-neutral approach to domestic violence. Four of the five aims Pittplace's main multi-agency initiative, the Pittplace Topic Group, set out on its formation were gender-neutral and referred only to victims of domestic violence (one aim was gendered, referring to women and children). Also, in the research period, the Topic Group became the coordinating group for Pittplace's first crime and disorder strategy on domestic violence. This strategy defined domestic violence as a gender-neutral issue "...the physical, sexual or emotional abuse inflicted on a spouse or partner by the other or others known to them..." (Pittplace Community Safety Partnership, 1998). Sometimes, though, this strategy referred generally to victims but other times it referred specifically to women and children. In Pittplace's other multi-agency initiative, the Pittplace Forum, the approach was gendered and discussions throughout centred on women's experiences of domestic violence and service provision to women.

As the Pittplace volunteer recognized, the commitment among some individuals and organizations in the town to a gender-neutral position on domestic violence was not shared by organizations in other areas in Hillshire. Certainly, in Steelsite, none appeared keen to include men.

\section{Steelsite}

Research interviews in Steelsite's domestic violence support organizations illustrated these organizations' commitment to a gendered approach. To the question, "...what is the [organisation name]...", interviewees said, inter alia:

It's a...community based organisation that helps women that have suffered from or who are suffering from domestic violence in some form.

It's a project that offers support to women who are either in abusive relationships, want to leave abusive relationships or have left abusive relationships.

Our main objectives are to be working with women specifically around the issues of domestic abuse.

Just one organization in Steelsite responded to men experiencing domestic violence. Even representatives from this organization, though, did not seem as 
keen as the Pittplace volunteers were to encourage that men's domestic violence victimization be seen as serious and significant. Indeed, in a research interview, one representative was keen to emphasize that, although the organisation responded to men, it was "...overwhelmingly women..." who used its services.

Steelsite's multi-agency initiative, the Steelsite Forum, also took a gendered approach. One interesting point here concerned the attendance in this initiative's meetings of the one organization in Steelsite that responded to both women and men, the Gamma Project. Although the other domestic violence support groups in Steelsite were among the best attendees in these meetings, the Gamma Project attended just once and, throughout the research period, seemed the odd one out. The Steelsite Forum was also consistently gendered in its aims. Rather than referring generally to victims or perpetrators, the forum's aims were specific that women and children were "...affected by..." domestic violence and that perpetrators were "...male perpetrators...". The forum also promoted a gendered approach in a multi-agency strategy that it published in 2000. The definition of domestic violence contained in the strategy “....reflect[ed] the reality..." (Steelsite DVF, 2000, p 1) that:

violence in a domestic setting is clearly a gender issue. Overwhelmingly, women and children experience violence and abuse from men. Women do not perpetrate violence or abuse against men or children to anywhere near the same extent. (Steelsite DVF, 2000, p 1)

Indeed, the definition in the strategy specified that domestic abuse "... overwhelmingly concerns men's abuse of power over their female partners or ex-partners..." (Steelsite DVF, 2000, p 1). The forum's other work in the research period was also grounded in a gendered approach - as evidenced by a research project, undertaken between the forum and Steelsite University, on women's help-seeking for themselves and their children.

Thus, in Pittplace, there were contradictions and tensions in how domestic violence was understood but there were no contradictions and tensions in Steelsite - here, domestic violence was a gendered issue and suggestions otherwise were just not voiced. The dominant framework in Steelsite was, without question, gendered.

Not only does the approach taken in Steelsite reflect that traditionally taken in most feminist theorizing about domestic violence, it also reflects that traditionally taken by the government (Parliament, 1974-1975; Home Office, 1986; Home Office, 1990; Women's Unit, 1999; Home Office et al., 2000). More recent government discourse on domestic violence, however, appears more ambivalent on whether or not domestic violence is a gendered issue. Certainly, the August 2002 Break The Chain awareness raising leaflet is gender-neutral throughout and states that "...domestic violence may happen to anyone..." 
(Home Office, 2002, p 2). The only indication that domestic violence is a gendered issue comes as the leaflet discusses support provision, explaining that refuges are places "... where women and children can live free from violence..." (Home Office, 2002, p 7). Likewise, the 2003 Safety and Justice Paper takes a much more gender-neutral position in discussions on the issue than that taken in earlier government discussions. The paper begins with the information that "...one in four women and one in six men will suffer domestic violence at some point in time..." (Home Office, 2003, p 8) but does not acknowledge the differences between the experiences of those one in four women and one in six men. ${ }^{6}$ The definition of domestic violence used in the paper is, implicitly, gender-neutral - “...any violence between current and former partners in an intimate relationship, wherever and whenever the violence occurs. The violence may include physical, sexual, emotional and financial abuse..." (Home Office, 2003, p 8). The foreword to the recent National Report states that "...89\% of victims who suffer sustained domestic violence are female..." (Home Office, 2005, p 2). Nonetheless, the word victim is used throughout the report and the definition of domestic violence that is promoted in the report is explicitly gender-neutral - “...any incident of threatening behaviour, violence or abuse (psychological, physical, sexual, financial or emotional) between adults who are or have been intimate partners or family members, regardless of gender or sexuality..." (Home Office, 2005, p 7, italics supplied). In other discussions, the government appears increasingly to avoid using gendered language. The domestic violence section of the Home Office web-site mostly refers to victims and lives being damaged or lost. The only gendered description given is the information that domestic violence claims the lives of two women each week. The government has also established and is funding a new help-line for male victims of domestic violence, the Male Advice and Enquiry Line.

It is interesting why there appear to have been some shifts away from a gendered position on domestic violence in government discourse and whether or not men are victims too also deserves attention (see Gadd et al., 2002, 2003; Dobash and Dobash, 2004). Nonetheless, what concerns me in this paper is how these governmental shifts and innovations around the gendered nature of domestic violence were experienced at local level in Pittplace and Steelsite. Certainly, government shifts away from the conceptualization of domestic violence as gendered towards a more gender-neutral model were also clear in Pittplace while Steelsite struggled to retain the kind of feminist and womencentred approach that characterized the early refuge, Women's Aid and Rape Crisis initiatives of the 1970s. One effect of such differences was some obvious disagreement and division between organizations working within different parts of the same county. A further and perhaps not unrelated effect seems to have been the ways and extent to which Pittplace and Steelsite had moved towards the framework that has, since the early 1980s, come increasingly to dominate crime prevention approaches. 


\section{Crime prevention}

\section{Pittplace}

Since it first met in 1997, Pittplace's main multi-agency initiative on domestic violence, the Topic Group, was included in the town's crime prevention arrangements, operating within the Pittplace Crime Prevention Partnership. When this Partnership was reconstituted to become Pittplace's Crime and Disorder Reduction Partnership (CDRP), the Topic Group became a sub-group of this partnership. As the Topic Group was included in Pittplace's CDRP, so the issue was included in Pittplace's first crime and disorder strategy. This strategy's action plan on domestic violence included 26 activities, into which the Topic Group's eight objectives were subsumed. The Topic Group wrote the action plan and became the coordinating group for it. Pittplace's crime and disorder developments also came increasingly to dominate both of the town's multi-agency domestic violence initiatives. The Topic Group and the forum discussed Pittplace's crime and disorder strategy in most meetings held in this period. In addition, one of eight Topic Group meetings was given over to the town's CDRP Director to give a presentation about the Act and Pittplace's strategy, as was one of five forum meetings. In one forum meeting a video explaining the Act was shown.

Evident in these sessions was, first, a feeling that things could only get better in Pittplace because "...ludicrously senior..." people were now involved and there were "...clear mechanisms to make sure senior people own[ed] this work...". Evident was, secondly, a sense that things could only get better for domestic violence following the Crime and Disorder Act. Indeed, when, after the presentation in the Pittplace Forum, an attending police Domestic Violence Officer expressed concerns about police responses to domestic violence, the director of the CDRP responded by saying “...the police have signed up, so we're going to have to use it...". Having senior people involved, the Act in place and the police signed up seemed to be the answer to domestic violence.

Three points might be mentioned. Firstly, the problem was clearly seen as a crime prevention one. Secondly, the proper response to it was seen as resting in crime prevention structures and, in particular, in crime and disorder structures. Thirdly, during the research period, it became increasingly obvious that services in Pittplace believed that domestic violence had become a main issue in the town since 1998. People clearly believed that, through being included in Pittplace's crime and disorder strategy, domestic violence as an issue had made it. The feeling appeared to be, as the CDRP director herself put it, that it was "...a credit to the Topic Group..." that domestic violence was included in Pittplace's first strategy and that the group's work had been "...rewarded..." with a position in the town's CDRP.

Clearly, such feelings are very different from those that have characterized traditional approaches to domestic violence. Most refuges are women-only 
organizations and have favoured collective, participative (Hague and Malos, 1998) structures over male-dominated, hierarchical, ludicrously senior ones. The feeling that it was a reward to be encompassed in a police/local government-led structure is very different from the refuge movement's philosophies and practices, which have centred on challenging, rather than colluding in, traditional power structures.

\section{Steelsite}

Steelsite's forum too had its roots in crime prevention, having been established by the Community Safety Unit of Steelsite City Council. Notwithstanding these crime prevention beginnings, the Steelsite Forum had strongly resisted becoming a crime prevention focused initiative. Certainly, following the Crime and Disorder Act 1998, the forum resisted being incorporated into Steelsite's CDRP by becoming a sub-group of this partnership. As one interviewee in Steelsite put it, there was an issue

about [the CDRP] being driven by the statutory agencies and domestic violence has its roots in the voluntary sector and how you balance that power thing out really. Because if the Domestic Violence Forum became a sub-group of [the CDRP] it would sort of lose its autonomy. And maybe some of its credibility.

These concerns reflected the forum's background and development. The forum's background to 1998 was one of autonomy, not operating under a broader structure in Steelsite. It worked from its own office base, which it shared with an organization working to support women sex workers in the city. The connection with such an organization was consistent with the forum's approach to its meetings and its work. The forum clearly viewed domestic violence as a violence against women issue, rather than a crime prevention issue. Forum activities exemplified this ideology, for example, a meeting on the experiences of women's groups working against male violence in postcommunist eastern Europe and involvement in a candle-lit vigil to mark the International Day to End Violence Against Women.

So, the Steelsite Forum resisted becoming involved in crime prevention measures and resisted being encompassed within the city's CDRP. Although this seemed consistent with the forum's development as an autonomous organization, focused on domestic violence as a violence against women issue, there were tensions. First, domestic violence did not have the prominent position in the city's first crime and disorder strategy that it had in Pittplace's strategy. In Steelsite, domestic violence, along with racial and homophobic harassment, was placed alongside 11 other objectives under one of four primary aims. Although in Pittplace there was excitement and expectation after 1998, in Steelsite there was clear concern about domestic violence's less than prominent position in the city's strategy. This concern was voiced in a 
multi-agency meeting in Steelsite, where the forum co-ordinator appeared to voice a common opinion - that domestic violence was not given "... as much weight..." as it deserved in the Steelsite strategy and was "...lumped together with..." other crime issues that were traditionally marginalized in police priorities. Concern was also voiced in interviews in Steelsite that domestic violence was rather hidden in the city's strategy - “...it was, I think, very inadequately dealt with. Which is very disappointing...". Although the feeling in Pittplace was that domestic violence had made it, the feeling in Steelsite appeared to be that it seemed no more, no less an issue in the city after the Crime and Disorder Act than it had been before 1998. The tension in the research findings in Steelsite was that, although the forum had avoided being lost in Steelsite's CDRP, not being in this partnership appeared to have created a sense that the issue had been lost.

A further tension was around funding. Steelsite's forum submitted a bid to the Home Office's Crime Reduction Programme (CRP). The forum appeared to have done this on Steelsite CDRP's instructions, that partnership having warned the forum that it would be seen unfavourably were it not to bid. There are obvious power issues involved in this finding (see Welsh, 2003) but the important contradiction here is that an initiative that had resisted being encompassed in crime and disorder arrangements had nonetheless become involved in a flag-ship crime reduction programme. The forum did not become a sub-group of the CDRP and the forum's bid to the CRP did not succeed but nor could it retain autonomy in dealing with domestic violence as a feminist issue once the Home Office was active in the area.

In Steelsite, then, there were clearly tensions around the association between the multi-agency initiative, the Steelsite Forum, and crime prevention approaches in the city. This forum was not a crime prevention focused initiative but a women support centred one. Nonetheless, it could not and did not avoid crime prevention altogether. Even in Steelsite, then, crime prevention influenced the response to domestic violence.

Indeed, since the Home Office became involved in domestic violence in the late 1980s, most developments on the issue have taken place within the Home Office's programme on crime prevention and reduction ${ }^{7}$ rather than emerging from the women's liberation and feminism that characterized the responses of the 1970s and beyond. The 1990s focus on preventing repeat domestic violence certainly occurred within the Home Office's programme on repeat victimization (Lloyd et al., 1994; Hanmer and Griffiths, 1998, 2000; Hanmer et al., 1999; see also Morley and Mullender, 1994). Other domestic violence projects in the 1990s associated with Home Office crime prevention include the Domestic Violence Matters development project (see Kelly, 1999), which was funded by the Home Office Programme Development Unit and which is documented within the Home Office Research Studies series. The connection between Home Office crime prevention and domestic violence has continued 
since the 1990s and, in February 2000, the Violence Against Women (VAW) initiative was launched. Over 30 projects were funded under the VAW initiative, which also gave rise to the most comprehensive literature review on domestic violence since Lorna Smith's 1989 Home Office Research Study 107 (Taylor-Browne, 2001). The VAW initiative was part of the government's $£ 400$ million CRP, which also made funding available to developing crime reduction around burglary and through the use of closed circuit television. Indeed, domestic violence increasingly sits alongside offences such as burglary and street crime in the government's approach to crime reduction and even has a mini-site on the government's crime reduction website - the No.1 online information resource for the crime reduction community (http://www. crimereduction.gov.uk).

Possibly, the most obvious connection between Home Office crime prevention and domestic violence is seen in developments under the Crime and Disorder Act 1998. In the first crime reduction strategies, produced under the Crime and Disorder Act, domestic violence was specified as a priority for action in $86 \%$ of strategies and, as such, was the most common crime type specified (Phillips et al., 2000). The more interesting point here, though, concerns, not the predominance of domestic violence in these first-round crime and disorder strategies, but the background to it. In November 1998, the then Home Office Minister, Paul Boateng, wrote to CDRPs to remind them of the importance of addressing domestic violence in their audits and strategies (Women's Unit, 1999, Phillips, 2002). Although reflecting central government's directive approach to local crime reduction (Phillips, 2002), the background to its inclusion in crime and disorder strategies also reflects the government's approach to domestic violence. The government made a strong statement about what it thought domestic violence was and what it thought should be done about it by addressing it through crime and disorder, then the most ambitious crime reduction initiative that the new Labour government had developed.

These policy developments relate closely to local changes in Pittplace and Steelsite and other localities. Clearly, Pittplace was not alone in placing domestic violence in a crime and disorder environment following 1998. Also, Steelsite Forum's bid to the Home Office's CRP was indicative of the move to contractualization in service delivery that has come to characterize criminal justice services in general and domestic violence services in particular. Underfunding means that many organizations have no choice but to buy into the approach the government is promoting. So, in Steelsite, the forum could not afford (quite literally) not to follow the city's CDRP's instruction to bid to the CRP. As for the concern in Steelsite about domestic violence's position in the city's crime and disorder strategy, groups that do not approach domestic violence through crime and disorder provisions clearly face feeling (and becoming) marginalized from an increasingly dominant government construction of gender, crime and safety. 
Yet, as in the shifts in the gender conceptualization of domestic violence, government crime prevention initiatives impacted locally but not uniformly. Difficulties and some discontinuity at both local and government level reflect broader tensions and challenges around issues of gender, crime and policy.

\section{Gender, crime and policy}

A move to gender-neutrality through the suggestion that men are victims too presents an obvious challenge to the feminist analysis that domestic violence is about male power over women and men's violence to women. With this challenge come, in turn, challenges for policy, research and theory (Grady, 2002; Goodey, 2005). Further, since gender-neutrality rests on the assumption that domestic violence "...may happen to anyone..." (Home Office, 2002, $\mathrm{p} 2$ ), the approach associated with it is to provide services to anyone - women or men. This approach starts from the understanding, as the Pittplace volunteers put it, that it is important to include men and promotes male victims' rights to service provision and encourages broadened and increased access to, and equal opportunities in, such provision. Thus, a move to gender-neutrality challenges feminist analyses about male power and male violence but also challenges the women-focused service provision that is associated with these analyses.

There are also clear tensions between the original women centredness of the refuge movement's approach and those associated with crime prevention. A move to crime prevention is a move away from a feminist approach since, in the move to crime prevention measures, attention turns away from feminist theorizing about gendered power relations and away from feminist activism and campaigning about the connections between men's individual and collective power. Such work on men and power has been central to feminist praxis on domestic violence. A move to crime prevention is a move from feminist politics, philosophy and praxis but it is also a move from a victim services approach and, associated to this, from domestic violence survivors' place as victims. The focus becomes prevention rather than service provision to individual women as victims. The tension here is not so much the focus on prevention since a future free from violence has been the vision around which feminist campaigning has organized - "...until women and children are safe..." (http://www.womensaid.org.uk). Rather, the challenge centres on the connection between prevention and victim services. The battered women's movement has been built on this connection. Refuges have endeavoured to provide appropriate services to assist women to develop the strength and resources needed in order to leave or change their abusive relationships (Hague and Malos, 1998). The tension comes in the exclusive focus on prevention that characterizes traditional crime prevention measures since, through their exclusive focus on prevention, these measures fail to connect prevention and victim services. 
Possibly, the most obvious tension in the shifts and changes in relation to gender and crime prevention is around the traditional ownership of the issue. Everybody, including the men's movement and the government, appears to be seeking ownership over domestic violence. Not only may domestic violence “...happen to anyone..." (Home Office, 2002, p 2), but “...we all need to take responsibility for helping to bring about change, and keep our friends, colleagues and communities safe from domestic violence..." (Scotland, 2005a). Domestic violence, it seems, has been reconceptualized as a collective cause. At the same time, it is increasingly celebrated as an "...horrific..." (Home Office, 2005, p 2) and “...evil..." (Scotland, 2005b) crime and is increasingly promoted in the government's “fight against crime". At both a practical level (as in research areas) and a conceptual level, this move to collective ownership over domestic violence seems connected to changes on gender and crime prevention in local and national policy discourse on domestic violence.

Through reducing the focus on gender politics, challenging women/victimcentred service provision, encouraging collective consciousness about domestic violence and promoting it within the general fight against crime, current policy responses have brought domestic violence in from an essentially isolated position. But the price that has been paid for this attention appears to be a dilution and denial of its uniqueness at political and individual level and a removal of it from sexual politics and feminist grassroots activism. Is this too high a price to pay?

\section{Conclusion}

Since the battered women's movement developed in the 1970s, feminist activists and researchers have campaigned ceaselessly to turn attention to and raise awareness about domestic violence. From the prominence of domestic violence in both popular and government discourse it would appear that these efforts have been successful and that feminist endeavours have been largely rewarded. Further, domestic violence's increasingly prominent position in government discourse has brought with it a considerable amount of government money. Much of this money has, of course, been used to further the government's own agenda on crime reduction rather than to fund refuges and other support organizations, whose funding situations remain precarious at best. Nonetheless, this funding has come at a time when the Rape Crisis Federation has been forced to close because of a funding shortage (see Jones and Westmarland, 2004).

In addition, a crucial part of feminist campaigning around domestic violence has been to challenge the assumption that "domestics" are a private matter by challenging the public/private dichotomy, which assumes that violence in a domestic setting is less serious than other violence. Feminists have claimed that this dichotomy has subverted women's protection by encouraging 
non-intervention in domestic violence - “...the law has served to institutionalise domestic violence symbolically by elevating the principle of non-interference in family life and patriarchal authority as paramount, above the protection of the wife..." (Edwards, 1996, p 191). In these challenges, activists and researchers have demanded that, instead, men be held accountable for their violence and abuse. The most enduring feminist demand in this regard has been that domestic violence be seen as real crime. This demand rests on an extensive literature, which suggests that the police in particular have considered "domestics" to be messy, problematic, unproductive, trivial and rubbish work (Reiss, 1971; Reiner, 1978; Faragher, 1985; Southgate, 1986; Edwards, 1989; Young, 1991), which have prevented them doing real police work (crime fighting). The literature contains repeated demands that domestic violence be seen as crime and be treated as such, regardless of its "private" nature. The suggestion that domestic violence is an "horrific" and "evil" crime seems consistent with feminist demands in this regard.

Is, though, domestic violence "just another crime" or is something lost by this re-positioning in meanings and practices? At a political level, although the refuge movement generally and Women's Aid in particular have not distanced themselves from the mainstream victim movement to the extent that the Rape Crisis movement has done (see Foley, 1996), refuges and other domestic violence support organizations have resisted incorporation into this movement. The refuge movement has retained considerable independence and political autonomy, maintaining, as Hague and Malos put it, “...a specifically feminist identity as a national movement of women committed to self-determination and relatively independent of both church and state..." (1998, p 38).

At individual level, domestic violence is a unique crime. The violence and abuse that women experience often occur in the context of an ongoing relationship, characterized by considerable power differences. Although wanting the violence to stop, many women do not want this relationship to end and their involvement and investment in criminal justice is often dependent on their perceptions about the changes, good and bad, that a call to the police, publicity, a prosecution, etc. might bring for themselves and their children (see Hoyle and Sanders, 2000). Although other victims are not an homogenous group, different from domestic violence victims but somehow the same as each other, there are several factors that are uniquely relevant to domestic violence and the response required for women and their children. ${ }^{8}$

In many ways, the problem is that which has long troubled feminists in the battered women's movement - is it appropriate to sacrifice politics and philosophy for a greater profile and prominence to the issue?

One of the dilemmas of the refuge movement has always been between, on the one hand, staying true to its ideals and, on the other, trying to provide the best possible services for women and children - and facing possible co-optation 
in the search for funding to provide these services. (Hague and Malos, 1998, p 195; see Foley, 1996)

This problem also appears in the prevailing policy response to domestic violence and, in particular, in how this policy response has developed at local level in areas such as Pittplace and Steelsite, where contradictions and competing positions were obvious. The gender-neutral analysis adopted in Pittplace offered a very obvious challenge to the feminist framework that has traditionally dominated how the problem has been conceptualized. The analysis of services in Pittplace that domestic violence was a crime prevention problem and that the answer or the proper response to it could be found in crime prevention measures, most obviously the Crime and Disorder Act, was also very different to the one that, in centralizing gender, power and service provision, the refuge movement has promoted. In Pittplace, domestic violence had, indeed, gained recognition as an horrific crime and, as an issue, appeared anything but isolated. Nonetheless, the possibility that this mainstreaming brought with it an obfuscation of domestic violence's uniqueness was a very real one.

In Steelsite, domestic violence was seen as a gendered issue and services were also committed to seeing it as a violence against women issue rather than a crime prevention issue. Indeed, Steelsite's partnership initiative tried hard to avoid the city's crime prevention structures (sometimes, more successfully than others). The framework in Steelsite was, then, much closer to the feminist one that has traditionally dominated. However, and more likely than not related, services in Steelsite appeared concerned about domestic violence's marginalization rather than escalation in importance, particularly in its "lumping together" with racial and homophobic harassment in Steelsite's crime and disorder strategy.

Ultimately, whether, in encouraging the idea that men are victims too and/or including domestic violence under the broader fight against crime umbrella (and, thus, in popularizing domestic violence and celebrating its nature as a crime), local and national policy responses will be viewed as a move in the right direction or a step too far will depend on the extent to which policy is translated into practical changes for domestic violence survivors. The concern about these local and national policy developments is that survivors' needs come to be forgotten in a policy environment in which the reality of domestic violence is silenced by the rhetoric of collective concern and action.

In Pittplace, domestic violence had increased in prominence but had its roots and reality been lost in the rush to take on the problem? More to the point, had the practical response to survivors changed (improved) because "ludicrously senior people" owned the work? Services in Pittplace clearly assumed the answer to this question was yes but domestic violence provision in the town remained poor and dedicated domestic violence organizations continued to 
face an uncertain financial future. Further, if, as is commonly suggested, the classic example of collective action, the partnership response, can lead to greater coordination in domestic violence services, I found no such connection between partnership initiatives and service provision to women and their children in Pittplace and Steelsite. Rather, there was a noticeable disassociation between this collective action, services on domestic abuse and women's potential to survive male violence (Welsh, 2005).

Arguing to retain feminist politics and praxis in domestic violence responses is not to suggest that men's domestic violence victimization should also be silenced or that crime prevention measures are never appropriate in domestic violence (see Lloyd et al., 1994; Hanmer and Griffiths, 1998, 2000; Hanmer et al., 1999; Grady, 2002). Nor is questioning the value of repositioning it as just another crime to suggest that domestic violence should remain "behind closed doors". Rather, these arguments and questions are to suggest that the move to the collective ownership over domestic violence is not an unproblematically good thing. Certainly there is little evidence that male offending in intimate and familial relationships is declining as a result of these conceptual and policy shifts. The single most significant risk to women's safety and the safety of their children continues to be the entering into of an intimate relationship with a man and women remain more likely to be raped, threatened, assaulted and murdered by men they know and, in particular, by men with whom they are having or have had a "romantic" attachment. Nor is there any evidence that these shifts have brought either a challenge to the development and dynamics of the locations in which male power is most operationalized - the home and family - or to the model of masculinity, parenting and husbanding that is learnt by boys and teenage men within such locations.

\section{Notes}

1 During the research period, I assumed a participant-as-observer (Gold, 1958) role in these three initiatives, observing their meetings and their other social settings. I attended seven PDVTG meetings, five PMADVF meetings, and six SDVF meetings. I also attended a gathering where a domestic violence drama initiative was being piloted to PDVTG attendees; a PDVTG "workshop" to examine the Crime and Disorder Act 1998 in Pittplace; a conference on domestic violence for Pittplace health practitioners, organised by the Pittplace District General Hospital NHS Trust representative on the PDVTG and the PMADVF; some SDVF Management Committee meetings; the SDVF Annual General Meeting; a conference on community safety, hosted by Steelsite's Crime and Disorder partnership; some meetings of a Hillshire-wide multi-agency domestic violence initiative, the Hillshire Domestic Violence Working Group (HDVWG); the launch of the HDVWG's “Just Stop It" awareness raising campaign; the National Domestic Violence Officers' Conference, hosted by Hillshire Police; and held meetings with the SDVF co-ordinator, the HDVWG secretary, and a senior Hillshire Police officer, based at Hillshire Police Headquarters, with special responsibility for domestic violence (see Welsh, 2003).

2 Sixty semi-structured interviews (both face-to-face and telephone) were conducted with practitioners, middle managers and agency heads in agencies and organizations in Pittplace and Steelsite. In addition, those sitting on each area's Crime and Disorder partnerships were interviewed, as were 
representatives from services in neighbouring towns, Millerton and Belleton. One focus group interview was conducted in Pittplace (see Welsh, 2003).

3 Lorna Smith (1989) claims that one of the earliest reported English cases was in 1395 when a woman brought witnesses before an ecclesiastical court to testify that her husband had attacked her, wielding a dagger and breaking her bones. Husbands have, for centuries, used systematic and serious violence to punish, dominate and control their wives as a matter of prerogative (Dobash and Dobash, 1980). Husbands had rights over their wives that were clearly articulated in English common law, including the right to correct and chastise. Husbands' right to reasonable chastisement persisted until 1891 (Freeman, 1979). Their right to rape persisted until 1991.

4 Clearly, word limitations mean that discussions here are limited as regards both details about feminist theorizing on domestic violence and the diversity of such theorizing. For a more detailed analysis of how feminist theories on domestic violence have developed and the differences that have emerged within and between such theories, see Mooney (2000).

5 An examination of the differences in and development of feminism and the refuge movement's position on gender is outside the scope of this discussion. Certainly, the position now of both Women's Aid and Refuge is that some men do experience domestic victimization. This position is clearly less clear cut than that 30 years ago of the founders of the battered women's movement. Yet, the general feminist framework has been and remains gendered.

6 Certainly, although the 1996 British Crime Survey (BCS) suggested such comparable victimization (confined in the BCS to physical assaults and/or frightening threats between "intimate partners"), the BCS also found that women experienced higher levels of repeat victimization over the last year. Women were also twice as likely as men to have been injured by a partner in the last year and were three times as likely to have experienced frightening threats. They were also more likely to report feeling "very upset" on the last occasion they were assaulted and found assaults considerably more frightening. The effects were also longer lasting for women. Finally, almost no men defined their experiences as a crime but $39 \%$ of chronic female victims (those assaulted three or more times in the last year) defined their most recent experience as such (Mirlees-Black, 1999).

7 The Home Office became involved in domestic violence with the publication of Home Office Circular 69/86, which, although focused on police responses to rape, contained recommendations about policing domestic violence. The 1986 Circular was followed by Home Office Circular $60 / 90$, which was dedicated to police responses to domestic violence, and which set out extensive guidance on appropriate policing in domestic violence cases.

8 Indeed, more recent literature has retreated from the demands in the literature of the 1970s and 1980s that domestic violence be treated as other violent crime to suggest that, in domestic cases, criminal justice intervention should be flexible - "...the role of legal sanctions in each case [should] vary from being central, marginal or completely irrelevant according to the particular circumstances of each individual victim..." (Hoyle and Sanders, 2000, p 33; see Stanko, 1997; Hoyle, 1998).

\section{References}

Bograd, M. (1988). Feminist Perspectives on Wife Abuse: An Introduction. In Yllo, K. and Bograd, M. (eds) Feminist Perspectives on Wife Abuse. Newbury Park: Sage.

Department of Health (1995a). Child Protection: Messages from Research. London: HMSO.

Department of Health (1995b). Domestic Violence and Social Care. London: HMSO.

Department of Health (1997). Local Authority Circular: Family Law Act 1996, Part IV Family Homes and Domestic Violence. London: Department of Health.

Department of Health (1999). Working Together to Safeguard Children. London: HMSO.

Department of Health (2000). Domestic Violence: A Resource Manual for Health Care Practitioners. London: HMSO. 
Department of Health, Welsh Office, Scottish Office Department of Health, Department of Health \& Social Services Northern Ireland (1998). Why Mothers Die: Report on Confidential Enquiries into Maternal Deaths in the United Kingdom 1994-1996. London: The Stationery Office.

Department of the Environment, Transport and the Regions, The Women's Unit and The Department of Health (1999). Relationship Breakdown: A Guide for Social Landlords. London: DETR Publications.

Dobash, R.E. and Dobash, R. (1980). Violence Against Wives. Shepton Mallett, Somerset: Open Books.

Dobash, R.E. and Dobash, R. (1992). Women, Violence and Social Change. London: Routledge.

Dobash, R.E. and Dobash, R. (2004). Women's Violence to Men in Intimate Relationships, Working on a Puzzle. British Journal of Criminology. Vol. 44, No. 3, pp 324-349.

Edwards, S.S.M. (1989). Policing 'Domestic Violence': Women, the Law and the State. London: Sage.

Edwards, S.S.M. (1996). Sex and Gender in the Legal Process. London: Blackstone Press.

Faragher, T. (1985). The Police Response to Violence Against Women in the Home. In Pahl, J. (ed.) Private Violence and Public Policy. London: Routledge \& Kegan Paul.

Foley, M. (1996). Who is in Control?: Changing Responses to Women Who Have Been Raped and Sexually Abused. In Hester, M., Kelly, L. and Radford, J. (eds) Women, Violence and Male Power. Buckingham: Open University Press.

Freeman, M.D.A. (1979). Violence in the Home. Farnborough: Saxon House.

Gadd, D., Farrell, S., Dallimore, D. and Lombard, N. (2003). Equal Victims Or The Usual Suspects? Making Sense of Domestic Abuse Against Men. International Review of Victimology. Vol. 10, No. 1, pp 96-116.

Gadd, D., Farrell, S., Lombard, N. and Dallimore, D. (2002). Domestic Abuse Against Men In Scotland. Edinburgh: Scottish Executive.

Gold, R.L. (1958). Roles in Sociological Fieldwork. Social Forces. Vol. 36, No. 1, pp 217-223.

Goodey, J. (2005). Victims and Victimology: Research, Policy and Practice. London: Pearson.

Grady, A. (2002). Female-on-Male Domestic Violence: Uncommon or Ignored? In Hoyle, C. and Young, R. (eds) New Visions of Crime Victims. Oxford: Hart Publishing.

Hague, G. and Malos, E. (1998). Domestic Violence: Action for Change. Cheltenham: New Clarion Press.

Hanmer, J. and Griffiths, S. (1998). Domestic Violence and Repeat Victimisation. Police Research Group Briefing Note No. 01/98. London: Home Office.

Hanmer, J. and Griffiths, S. (2000). Reducing Domestic Violence... What Works? Policing Domestic Violence. Policing and Reducing Crime Briefing Note. London: Home Office.

Hanmer, J., Griffiths, S. and Jerwood, D. (1999). Arresting Evidence: Domestic Violence and Repeat Victimisation. Police Research Series Paper No. 104. London: Home Office.

Harwin, N. (1999). A Perspective from Women's Aid. In Harwin, N., Hague, G. and Malos, E. (eds) Multi-Agency Responses and Domestic Violence. London: Whiting and Birch.

Home Office (1986). Violence Against Women. Home Office Circular 1986/69. London: Home Office. 
Home Office (1990). Domestic Violence. Home Office Circular 1990/60. London: Home Office.

Home Office (2000). Domestic Violence: Revised Circular to the Police. London: Home Office.

Home Office (2002). Break The Chain. London: Home Office.

Home Office (2003). Safety and Justice: The Government's Proposals on Domestic Violence. London: Home Office.

Home Office (2005). Domestic Violence A National Report. London: Home Office.

Home Office, Women's Unit, Crown Prosecution Service, The Department for Education and Employment, The Department of The Environment, Transport and The Regions, The Department of Health, The Lord Chancellor's Department, The Department of Culture, Media and Sport (2000). Multi-Agency Guidance for Addressing Domestic Violence. London: Home Office.

Hoyle, C. (1998). Negotiating Domestic Violence: Police, Criminal Justice and Victims. Oxford: Clarendon Studies in Criminology, OUP.

Hoyle, C. and Sanders, A. (2000). Police Response to Domestic Violence: From Victim Choice to Victim Empowerment? British Journal of Criminology. Vol. 40, No. 1, pp 14-36.

Jones, H. and Westmarland, N. (2004). Remembering the Past but Looking to the Future. http://www.rapecrisis.org.uk/history.htm.

Kelly, L. (1999). Domestic Violence Matters: An Evaluation of a Development Project. Home Office Research Study No. 188. London: The Stationery Office.

Lloyd, S., Farrell, G. and Pease, K. (1994). Preventing Repeat Domestic Violence: A Demonstration Project on Merseyside. Crime Prevention Unit Paper No. 49. London: HMSO.

Mirlees-Black, C. (1999). Domestic Violence: Findings from a New British Crime Survey Self-Completion Questionnaire. Home Office Research Study No. 191. London: Home Office.

Mooney, R. (2000). Gender, Violence and the Social Order. Basingstoke: Macmillan.

Morley, R. and Mullender, A. (1994). Preventing Domestic Violence to Women. Police Research Group Crime Prevention Unit Series Paper No. 48. London: Home Office.

Parliament (1974-1975). Report from the Select Committee on Violence in Marriage, Together with the Proceedings of the Committee, Vol. 1. Report. London: HMSO.

Phillips, C. (2002). From Voluntary to Statutory Status: Reflecting on the Experience of Three Partnerships Established under the Crime and Disorder Act 1998. In Hughes, G., McLaughlin, E. and Muncie, J. (eds) Crime Prevention and Community Safety New Directions. London: Sage.

Phillips, C., Considine, M. and Lewis, R. (2000). A Review of Audits and Strategies Produced by Crime and Disorder Partnerships In 1999. Home Office Briefing Note No. 08/00. London: Home Office.

Pittplace Community Safety Partnership (1998). Pittplace Crime and Disorder Audit. Pittplace: Pittplace Community Safety Partnership.

Reiner, R. (1978). The Blue Coated Worker. Cambridge: Cambridge University Press.

Reiss, A.J. (1971). The Police and the Public. New Haven: Yale University.

Scotland, P.J. (2005a). http://press.homeoffice.gov.uk/press-releases/Tackling_Domestic_ Violence_A_Pri.

Scotland, P.J. (2005b). http://press.homeoffice.gov.uk/press-releases/A_Month_Of_ Action_To_Raise_Aware. 
Smith, L.J.F. (1989). Domestic Violence. Home Office Research Study No. 107. London: Home Office.

Southgate (1986). Police Public Encounters. Home Office Research Study No. 77. London: Home Office.

Stanko, E.A. (1997). Should I Stay or Should I Go? Some Thoughts on the Variants of Intimate Violence. Violence Against Women. Vol. 3, No. 6, pp 629-635.

Steelsite Domestic Violence Forum (2000). Multi-Agency Strategy on Domestic Abuse. Steelsite: Steelsite Domestic Violence Forum.

Sutton, J. (1978). The Growth of the British Movement for Battered Women. Victimology. Vol. 2, No. 3-4, pp 576-584.

Taylor-Browne, J. (2001). What Works In Reducing Domestic Violence? A Comprehensive Guide For Practitioners. London: Whiting and Birch.

Welsh, K. (2003). Multi-Agency Approaches to Domestic Violence in a County in Northern England. Unpublished PhD Thesis. Sheffield: University of Sheffield.

Welsh, K. (2005). The disassociation between domestic violence service provision and multi-agency initiatives on domestic violence. International Review of Victimology. Vol. 12, No. 3, pp 213-234.

Welsh, K. (2008). Partnership or Palming Off? Involvement in Partnership Initiatives on Domestic Violence. Howard Journal of Criminal Justice. OnlineEarly Articles Published article online 30 January 2008.

Women's Unit (1999). Living Without Fear: An Integrated Approach to Tackling Violence Against Women. London: HMSO.

Young, M. (1991). An Inside Job. Oxford: Oxford University Press. http://www. womensaid.org.uk. 